\title{
AMNESTY FOR COUP PERPETRATORS IN FIJI: CREATINGPEACE OR POTENTIAL FOR FUTURE CONFLICT
}

\author{
Natasha Khan \\ The University of the South Pacific (USP), Suva, Fiji \\ Corresponding Email: natasha.khan@usp.ac.fj
}

\begin{abstract}
In many countries that have experienced coups d'état, the coup executors, particularly senior ranking personnel of the state military, granted themselves some form of amnesty and/or impunity from prosecution. While this is effective in achieving short-term peace, sustainable peace remains elusive. This paper challenges the issues surrounding the question of amnesty within such settings, and considers the significance of this neglect. Additionally, most studies do not address the issue of amnesty and impunity for political crimes as the international focus tends to be mostly on gross violation of human rights. However, conflicts in most small island developing states (SIDS) do not reach the intensity to produce such gross violations of human rights though evidence shows that these conflicts can be equally costly to the country (Chauvet, et al, 2010, p. 976).
\end{abstract}

Keywords: Amnesty, Small Island developing States, Coup D'état

\section{Maximalists, Minimalists and Moderates on Amnesty}

Literature on amnesty is extensive and covers many issues spanning the position of opponents, proponents and those in the middle. However, few scholars have written on amnesty for political crimes and its link with coups d'état.

Amnesty has evolved gradually from the stately pardon for any crime to maintaining political peace after international wars to a modern response to internal conflicts (Joinet, 1985). In recent decades, amnesty provisions have entered the transitional justice discourse and provoked strong debates for and against it. In the 1970s, organizations and persons rallied for amnesties for political prisoners in different parts of the world but in the 1980s, the focus shifted from amnesty to protest against impunity when a number of Latin American dictators granted themselves 'self-amnesty' while they were still in power (Joinet, 1997, pp. 3-4). While the condemnation for impunity was strong at this stage, it had not gained international momentum. The third shift was noted in the early 1990 s when amnesties were increasingly negotiated as part of the peace agreements in countries moving towards democratization (Joinet, 1997, pp. 3-4). Since the South African Truth and Reconciliation Commission, the focus has shifted from blanket and unquestionable amnesties to 'conditional-amnesty' and is increasingly used with other transitional justice mechanisms (Sarkin, 2004; Mallinder, 2007a). The ascendancy of human rights as a fundamental principle directing state conduct increased international and national debates on amnesty and linked it to impunity during the 1990s (Human Rights Watch, 2005: 13; Orentlicher, 2004; Kritz, 2002, p. 33). Additionally, increasing use of information and communication technologies, has allowed people from all walks of life and different countries to participate in amnesty debates (Freeman, 2009, p. 1). Amnesty is a contentious issue and there 
is no single cohesive view on amnesty as maximalists, minimalists and moderates within the transitional justice field justify their perspectives on amnesty.

Snyder and Vinjamuri (2003, pp. 39-40) argue for amnesty on the basis that in countries coming out of conflict, former regime members who retain strong influence, could derail the peace process, if they feel threatened by possible legal action. Similarly, Randelzhofer \& Tomuschat, (1999) advocate amnesty negotiated in peace agreements, to accommodate members of outgoing regimes, as they are unlikely to give up their potential to destabilize the peace process unless the threat towards them is lessened. Amnesty is granted to maintain national unity (Rigby, 2001); to acquiesce to the demands of members of a former regime who could otherwise destabilize the peace process (Snyder \& Vinjamuri, 2003); as an incentive to acquire information about committed atrocities (Tutu, 1999, p. 25) and to negotiate ceasefire, disarmament, etc. (Mallinder, 2007a).

While Cook (1997) argues against amnesty by emphasizing that it needs to take into account the demands of people in their country as well as adhere to international and national human rights standards, Mendez (1997, p. 7) states that blanket amnesties even if conducted after democratic debate are still an abuse of 'majoritarianism' as they ignore the rights of the minority who are usually the victims in such scenarios. Orentlicher argues that impunity is most common in states that have a weak judiciary, prevalent corruption and an entrenched patronage system (Commission on Human Rights, 2004). Opponents focusing on blanket amnesty argue that it shows little compassion for victims (Tutu, 1999: 30-32); would portray a culture of impunity (Kritz, 2002, p. 33); would embolden perpetrators to commit further atrocities (Human Rights Watch, 2009), and may undermine the rule of law (Cook, 1997). International conventions such as the Geneva Conventions and others oppose amnesties for gross violations. Amnesty proponents argue that it maintains political stability, but opponents cite many examples where amnesty has not led to lasting peace, and they claim that it may instead embolden perpetrators, while ignoring victims' calls for justice (Human Rights Watch, 2009). This is demonstrated in the case of Fiji, as after each coup by the military, the perpetrators and their supporters were granted sweeping amnesty.

But in recent years, Mallinder (2007) and Freeman (2009) have questioned the two divergent perspectives and reignited amnesty debates. Amnesty discourse needs to go beyond impunity versus justice or peace versus justice, to consider justice and human dignity, which accounts for both "pro-prosecutions and pro-amnesties" (Freeman, 2009, p. 109). Rather than discarding amnesty altogether, conditional amnesty could be utilised to encourage offender engagement in national reconciliation and reconstruction (Mallinder, 2007a, p. 39).

Amnesties for perpetrators of gross violations of human rights were acceptable prior to the rise of human rights standards, but would be unacceptable today. The evolving debate on amnesty is indicative of dynamic changes in the field of transitional justice; the strong stance of the human rights agenda; the push for greater accountability for gross human rights violations; and the acknowledgement of various strengths and weakness of using amnesty and how it could be finetuned. Discussions and debates on amnesty for political crimes that do not reach the benchmark of gross violations is negligible, although amnesty and impunity for these crimes had, in many situations, led to increased repression, and renewed and escalated violence. For instance, Iliff (2009: 162) states that in Zimbabwe there were no prosecutions of ZANU (PF)-affiliated perpetrators of political crimes and there was concern that these powerful perpetrators would remain in power and may "instigate further violence in an effort to retain the protections and privileges of power".

Gross violations of human rights is common is many larger countries that have a history of coups, such as Thailand, Pakistan and many others. However, the focus of this research was the reoccurrence of coups in SIDS, where the level of violence does not commonly reach to the levels 
of gross violations. It is apparent that the international community is still not giving much focus to the types and levels of conflicts that occur in SIDS, as the conflicts in these countries cannot be realistically comparable to conflicts in larger States.

\section{Methodology}

In total, 59 persons were interviewed using semi-structured questionnaires and 16 key informants were interviewed using the in-depth approach. While the number of respondents may seem low, the rationale for this research is not to have generalised findings but rather to get rich data with many issues identified and discussed in depth.

\section{Terminologies Defined Amnesty}

The definition of amnesty differs substantially between jurisdictions due to various catalysts to its introduction which ultimately shapes the character it takes (Mallinder, 2007a, p. 5). However, it is broadly defined as an act of forgiveness by the state to perpetrators. For the purpose of this paper, we will use Freeman's definition:

Amnesty is an extraordinary legal measure whose primary function is to remove the prospect and consequences of criminal liability for designated individuals or classes of persons in respect of designated offenses irrespective of whether the person concerned have been tried for such offenses in a court of law. (Freeman, 2009, p. 13)

\subsection{Political crimes}

There is no commonly accepted definition of political crimes as they are often deemed to be context specific. However, they are broadly understood to be crimes against the established political order. The term is wide ranging: from purely passive offences such as political dissidence to more violent actions against the prevailing social order that does not affect private rights (Van de Wyngaert, 1980, p. 106). Political crimes generally include acts such as "treason, sedition, rebellion, using false documents, anti-government propaganda, possessing illegal weapons, espionage, membership of banned political or religious organizations, desertion, and defamation" (Mallinder, 2007b, p. 22; Van de Wyngaert, 1980, p. 107) Political crimes include activities such as attempted coups d'état as this is deemed anti-government.

Common crimes can sometimes be regarded as political crimes as "under certain circumstances, namely when they are committed with a political purpose or when they have political consequences" (Van de Wyngaert, 1980, p. 95). Extradition law has been utilised to differentiate between common and political crimes by using three categories of tests: the political incidence test, the predominant motive test, and the political objective test (Van de Wyngaert, 1980, pp. 108-111). The political incidence test attempts to establish if there was political disturbance and that the act was part of a continued political struggle (Van de Wyngaert, 1980, p. 111). The predominant motive test occurs if the act is associated with a political objective, that the political character of the act is greater in proportion than the common crime element, and finally, "... that the means used must be either the only recourse available or proportionate to the desired political outcome" (Van de Wyngaert, 1980; Yakoob, 2000, p. 545). The political objective test "examines the specific nature of the act, without regard to the subjective motivation of the individual or whether the desired ends were political" (Van de Wyngaert, 1980, p. 542).

In conflict and amnesty discourse, to date, political crimes were most clearly defined by South Africa prior to the establishment of its Truth and Commission and that definition will be used by this paper as the standard. Accordingly, political crime was defined within South Africa context as follows:

Certain offences are recognized as "purely" political, eg. treason directed solely against the State and not involving a common or "ordinary" crime such as murder or assault or the dissemination 
of subversive literature. In certain circumstances, a "common" crime, even a serious one such as murder, may be regarded as a political offence. Here the following are the principal factors which are commonly taken into account by national courts:

i) The motive of the offender - i.e. was it a political motive (eg. to change the established order) or a personal motive (eg. to settle a private grudge).

ii) The context in which the offence was committed, especially whether the offence was committed in the course of or as part of a political uprising or disturbance.

iii) The nature of the political objective (eg. whether to force a change in policy or to overthrow the Government).

iv) The legal and factual nature of the offence, including its gravity (eg. rape could never be regarded as a political offence).

v) The object of the offence (eg. Whether it was committed against Government property or personnel or directed primarily against private property or individuals).

vi) The relationship between the offence and the political objective being pursued, (eg. The directness or proximity of the relationship, or the proportionality between the offence and the objective pursued).

vii) The question whether the act was committed in the execution of an order or with the approval of the organisation, institution or body concerned.

(The Groote Schuur Minute, 1991)

For the purpose of this paper, the focus will be on all political crimes, but more specifically on the overthrow of democratically elected government, the abrogation of the constitution, interference in elections, the undermining of the independence of the judiciary, restriction of personal liberty, and arbitrary detention of human rights defenders.

\section{Political Crimes: a Precursor to Gross Violations?}

While there is a higher occurrence of political crimes which are subsequently amnestied, international stakeholders continue to overlook this fact as the majority of international laws, peace building activities and projects are focused on international crimes. The issue of sovereignty is raised, particularly for political crimes, as it is argued that these should be addressed by the nation rather than international law. However, the neglect of political crimes within international law could be detrimental as political crimes, which have a higher occurrence in many internal conflicts, are considered a precursor to international crimes (Mallinder, 2007b).

One of the hypotheses of this paper is that, the international community and international law would be more effective in preventing conflicts from escalating by encouraging and/or pressuring for accountability, even for political crimes in countries where conflict is more structural than violent. Structural conflicts are invisible and implicit forms of violence that is manifested the inequalities in the social, political and economic structures of the society (Galtung, 1969, pp. 167-191). Most civil wars do not erupt suddenly out of isolated incidents: there is usually a build-up of tension and sporadic and low level of violence over a period of time.

State repression is a major risk factor because it can transform latent grievances into active antagonisms, especially when repression is indiscriminate, since quiescence offers little protection. Importantly, there is strong evidence that government repression is habit-forming and that past levels of repression have a powerful effect on current behaviour. (Thoms \& Ron, 2007, p. 695) 
This has been noted in Fiji, as after the 1987 coup, military was successful in repressing the community through intimidation and terror, and they used similar forms of repression but more intensively in the later coups. During this period, a series of control mechanisms has contributed to increased militarisation in Fiji during coups and a lack of cohesive protest by the population as the military presence increased. Since 2007, increasing numbers of decrees have limited the right to assembly and protest; instigated the arbitrary arrest of dissents and impunity for arresting officers; prevented blacklisted individuals (usually those who had protested against governments repressive actions) from leaving/entering the country; increased surveillance on human rights defenders and expulsion of expatriates who speak against the coup. Reports submitted to Fiji's Universal Periodic Reviews 2010 and 2014 document numerous cases of abuse by the interim government (OHCHR, 2009, 2014). For instance,

According to CCF (Citizen's Constitutional Forum) since April 10th 2009, at least 23 journalists, lawyers, human rights activists and religious leaders have been subject to arbitrary detention under the PER [Public Emergency Regulation] 2009, for up to 72 hours, for exercising their right to peaceful assembly and freedom of expression. CCF indicated that it has been informed of other cases of arbitrary detention and police brutality from people who wish to remain anonymous, and fears that there may be many more such cases. Several people were also detained and subjected to cruel and degrading treatment in the months following the coup. Four people have died in custody from the brutal treatment of military, police or prison officers since December 2006. (OHCHR, 2009, p. 5)

Figure 1 demonstrates that repression in Fiji peaked during coups d'état years of 1987, 2000 and 2007 (as the last coup occurred in late 2006). While it does not identify the intensity and pervasiveness of repressions, evidence from Fiji suggests that such controls are more widespread after the recent coup when compared to earlier ones.

Figure 1: Political Terror Scale for Fiji, 1986 - 2008

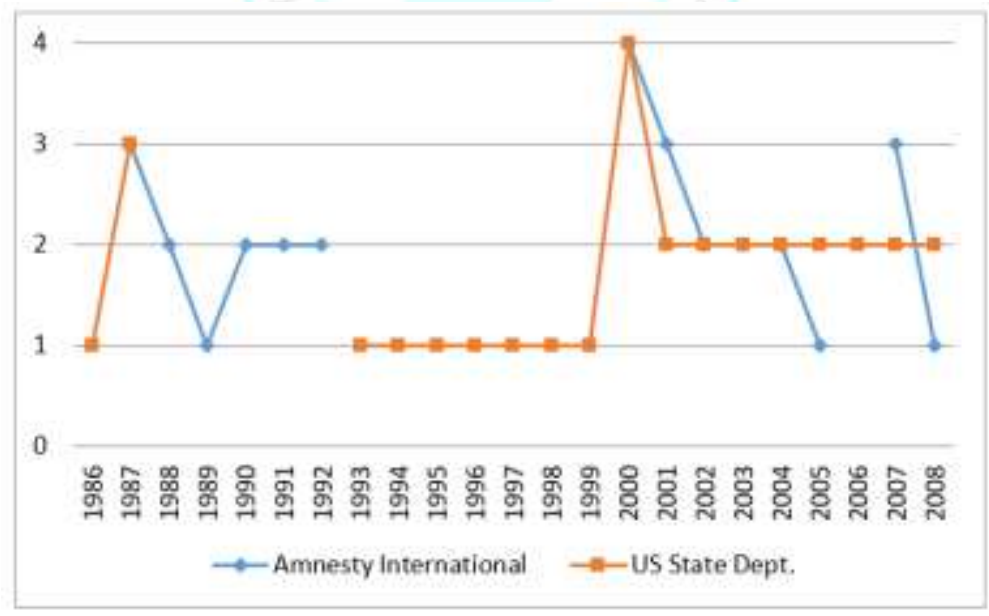

Source: Data downloaded from Political Terror Scale. [Online]. Available at:http://www.politicalterrorscale.org/download.php. [Accessed 30 July 2010]

It is argued that addressing the root causes of conflict at the initial stages, combined with accountability, establishing the rule of law and development, among other factors, could minimize tensions flaring up into protracted conflicts (Lederach, 2006; Collier, et al, 2003). While is it recognized that the "internal conflicts and their consequences fall within the domestic jurisdiction and therefore national sovereignty" (Deng, et. al., 1996, p. 1), however "sovereignty can no longer be seen as a protection against interference, but as a charge of responsibility 
where the state is accountable to both domestic and external constituencies" (Deng, et. al., 1996, p. 3). Human rights based approaches also assert that the state; which is the duty bearer of rights and is supposed to promote, protect and fulfill the rights of its citizens, and if it starts to oppress its citizens, it losses the legitimacy to argue for state sovereignty.

In Sierra Leone, after independence in 1961, it took almost 30 years for the conflict to escalate from tensions to violent conflict (Collier, et al 2003, p. 127). In South Africa, the latent restrictions on Africans were turned into explicit apartheid legislation systematically over a period of 57 years and it is argued that early pressure from the international community could have been effective in ending this conflict much earlier (Kelly, 2002, p. 42). Since the 1960s, UN worked consistently to dismantle apartheid in South Africa through its many resolutions and later with sanctions. It was collaborative actions of the international community through the UN and African states within the Organisation of African Unity (OAU) that eventually led to the termination of its apartheid policy (Mangu, 2011). Pressure from the international community pushed the South African leadership during the apartheid era to dismantle and reform their policies and practices.

The repeated failure to stem the ethnically-based political violence and hold perpetrators of human rights abuses to account created a climate of impunity in Kenya that led to cycles of violence. The atmosphere of distrust and division created by the longstanding lack of justice has been repeatedly manipulated by leaders in support of their own political agendas. While in Kenya the pressure stopped the violence, failure to sustain that pressure and to actually end impunity is likely to result in more violence sometime in the future. (Human Rights Watch, 2009, p. 81) [Emphasis added]

Similar scenarios are noted in almost all states experiencing civil wars: political crimes that do not fall within the category of international crimes are perpetrated by conflicting parties without accountability as the rule of law is weakened over a period of time. International community's pressure on SIDS who are infringing on human rights abuses and committing political crimes, could encourage these countries to reform their approaches during times of tension. For instance, after the 2000 coup, the Qarase government acknowledged that citizens of the country did not have much trust in the Fiji Police Force and agreed to collaborate with Australian government to have an Australian citizen head the Fiji Police Force and to open investigations on the death of numerous soldiers and rebels.

Evidence from some countries indicates that amnesties for political crimes have emboldened perpetrators to commit even worse crimes than before. For instance, in Angola, from 1990 onwards Jonas Savimbi and his UNITA group were granted at least six successive amnesties, but crimes continued and even worsened every time the conflict resumed (Human Rights Watch, 2009, pp. 61-68). After three amnesties in Sierra Leone, serious abuse of civilians by both rebels and government forces continued (Human Rights Watch, 2009, pp. 57-66). Amnesty for perpetrators in conflicts in Burundi has been documented at least six times between 1967 and 2006 (The Amnesty Law Database, 2015). During the Conflict Prevention and Resolution Forum, the Special Envoy to the Angolan peace process stated that UNITA should not have been granted further amnesties after the collapse of the Bicesse Accords. While some of the above amnesties were for international crimes, the majority of amnesties were for lesser political crimes, but little attention was given to this by human right activists, policy makers and the international community, including international organizations such as Human Rights Watch and Amnesty International. The heightened attention on amnesty for international crimes is understandable and, but the continued overlooking of amnesty for political crimes sets a dangerous precedent for countries with histories of structural conflicts.

Countries like Fiji are already showing signs of escalating tensions and violence. Fiji has had four coups; two in 1987, in 2000 and recently in 2006 and after each coup, military personnel 
have been granted amnesty. The 1987 coups were bloodless and apart from the release of a large number of prisoners to terrorize the coup protesters, there were few incidents of overt violence. This changed in the 2000 coup, which brought untold suffering to the country as widespread violence was committed against the Indo-Fijian community. The criminality arising out of this is seen as the legacy of impunity given to the 1987 coup makers. "The conferment of immunity from prosecution to Rabuka and his accomplices gave the 1987 coups its ultimate legitimacy", as it served not as a deterrent, but an inspiration, for the would-be perpetrators of 2000 coup (Chang, 2008, p. 11). Although some consider this argument not convincing as the 2000 coup was a civilian coup, it is evident that it was planned and carried out with the help of a rebel unit within the military. While the 2006 coup was not violent, it is more oppressive as the country has been under curfew for many months and there was increasing censorship and torture of media personnel, human rights activists and anyone who spoke against the regime. To date, four civilians have died while undergoing interrogation in police/military custody (OHCHR, 2009, p. 5). This pattern of escalating violence in Fiji indicates that after each coup, more violence is evident in comparison to previous coups. This pushes back the boundaries of tolerance.

\section{Amnesty and its Relationship with Coups d'états}

Figure 2 demonstrates the link between coups and amnesty. While it is generally assumed that amnesties were more readily granted in the 1960s, due to the lack of human rights awareness, data indicates the opposite, as only $15 \%$ of amnesties were granted for all violations related to coups in that era. This could be due to various factors: lack of information from those years; supremacy of the military within the countries concerned; with negligible threat of prosecution, perpetrators did not seek amnesty; lack of NGOs at national and international level to push for accountability; and lack of awareness among local populations to demand justice. This data suggests that the granting of amnesty has gained prominence alongside human rights advocacy. Figure 2 demonstrates this, as between 1990 s and 2000s, the majority of coup makers were granted amnesty. However, amnesty may have been more conditional, and may have required some form of disclosure, truth telling, ceasefire, disarmament, or vetting rather than the grant for a blanket amnesty which is more indicative of impunity. However, in some countries, blanket amnesty is still awarded. For instance, in Fiji, the amnesty for the 2000 coup was conditional, but for the 2006 coup unconditional amnesty was awarded.

Figure 2: Grant of Amnesty for Coup related offences, by Decade 


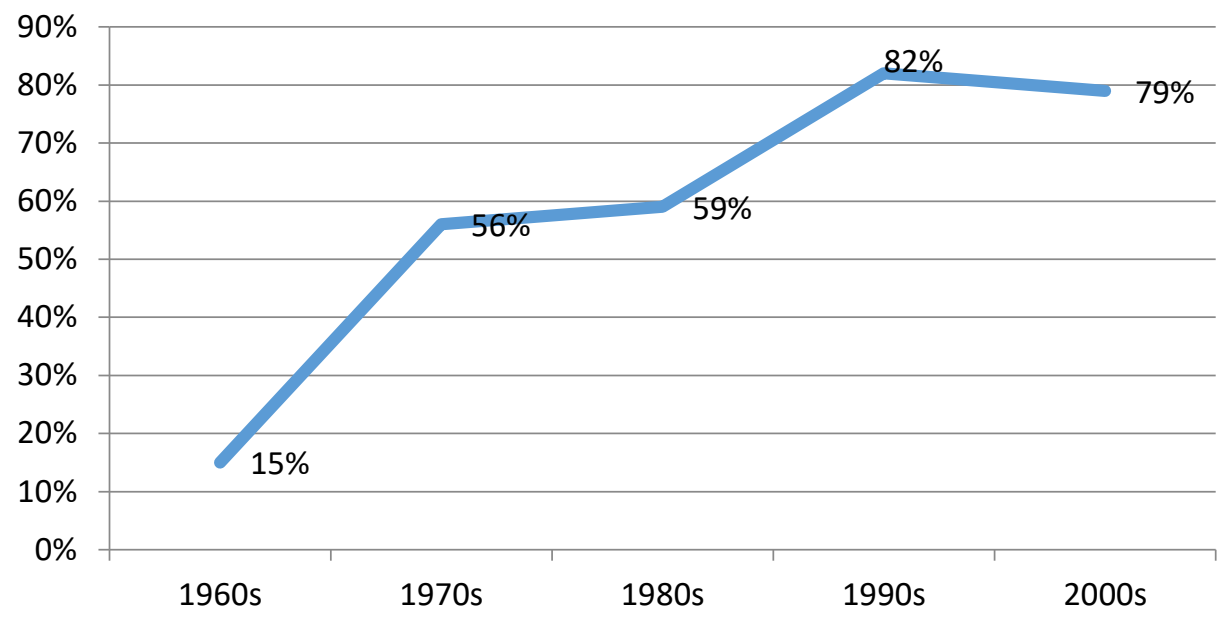

Amnesty is only one factor that leads to or deters coups. As stated above, socio-economic and developmental factors such as enhanced livelihoods, access to services, improved infrastructure, improved literacy rates, strengthened NGOs, and so on could also lower tension within a country and hence avoid the risk of coups. This is observed in Ghana, Nigeria, South Korea, and Brazil and elsewhere. On the other hand, in Sierra Leone, Liberia and many other African countries, the amnestied coup makers of the past have formed their own rebel groups when dissatisfied with the peace process, their diminishing role in the new government or for other reasons. Conflicts in many such countries that had initially started with tension, coups and counter coups have now become entrenched. It could be assumed, from Figure 2, that increasing amnesties in recent years have led to a decline in coups d'état, but a realistic analysis of the different countries presents a different picture. Attempted coups remain a continued threat in a number of countries, such as the Philippines. It is argued that international and national push to denounce amnesty for removal of democratic governments has the potential of deterring potential future coup perpetrators.

Country studies show that Fiji, Thailand, Pakistan, and Mauritania have implemented a 'rolling' amnesty meaning that after the execution of a coup, the coup makers are granted widespread amnesties. While the notion is to maintain the fragile peace and appease the military regime in power, it has been proved ineffective as a way of minimizing future coups as all these countries have recurring coups, nearly always led by the military. History indicates that appeasement of military regimes leads to more violations later as it indicates government weakness to the military (Citizens' Constitutional Forum, 2005: 2). In Fiji, the precedent for impunity was set in 1987 when Rabuka was awarded a blanket amnesty for staging the first coup, as this presumably emboldened others to execute coups and legitimize granting of amnesties (Lal, 2002).

\section{Minimalist approach to Amnesty in Fiji}

Researches show that in transitional countries, negotiations for or against amnesty could be a contentious issue, depending on the relative strengths of the perpetrators and society's demand for justice (Skaar, 1999;Zalaquett, 1992; Malamud-Goti, 1990). The delicate balancing act between maximalist, minimalist and moderate approaches towards amnesty indicates that amnesty should be granted for the sake of national unity if the perpetrators have the strength to destabilise the peace process (Neier, 1990; Nino, 1996). In Fiji, the minimalistic approach to amnesty has been utilised for all military coup perpetrators. Ironically, the Bainimarama led military had taken offence at a civilian coup perpetrator, George Speight, negotiating for amnesty. It seems that the military personnel consider themselves to be above the law, when it comes to being held accountable for their actions. 
Figure 3 demonstrates that a resounding $78 \%$ of the respondents consider amnesty for coup perpetrators as bad. A number of key informants also think that amnesty is bad as it sends the wrong signals to the coup perpetrators and to future generations.

Figure 3: Amnesty for Coup Perpetrators

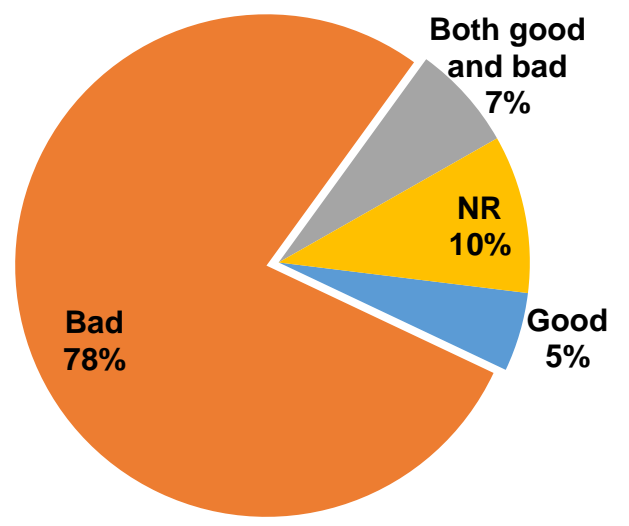

Yes, undoubtedly amnesty has encouraged the coup behaviour because it does not give space for accountability and justice to take place and if you don't deal with this, justice will never be done and there will always be resentments due to that and it also signals the message that it's ok carry out a coup. They continue to elude prosecution and I think that is a wholly unhealthy cycle that needs to be addressed. (Andrew Hughes - Former Commissioner of Fiji Police)

Some of the key informants were sceptical that the military could be held accountable as they were presently so powerful. John Rabuku also mentions a valid concern of many developing countries, the use of limited resources for thorough investigations and long prosecutions, and suggested that reparations which could allow some accountability of the perpetrators and provide some tangible compensation to the victims.

Chances of Bainimarama being prosecuted are very low, if they had prosecuted Rabuka and put him in jail, our history might have been different. (Imrana Jalal - Human Rights Activist) The thing is, people who come into power like this are not stupid, so before they hand over power they make sure that they have acquired amnesty and are safe from prosecutions. I am kind of person who likes to deal with issues and have some closure to it therefore I won't like to see our Courts being inundated with all these proceedings from the past, where many of our much needed resources would be diverted. But I would like to see a compensation fund set up and that there is some compensation hearing and that military could be occasionally liable and that compensation is paid to people affected. (John Rabuku - Ex-Director of Public Prosecutions)

Joseph Brown highlights a concern discussed earlier in this paper; if amnesty is given, what types of crimes it could cover,

Recently they have created immunity decrees and the wording says that all political decisions made will be covered under this, but shouldn't it be the courts to decide whether the decision made by police or military was a political motive or was it following directives from his superiors, when they arrest, torture or detain you? (Joseph Brown - Secretary to the late Ratu Sir Kamisese Mara during his enure as Prime Minister, Vice President and later President)

Figure 4 demonstrates that the majority of the respondents considered amnesty for military coup perpetrators to be unjust (61\%), 12\% were tolerant of such amnesty since the military led 
government had removed problematic structures in Fiji's society. Also, similar to concerns shown in Table $1,3 \%$ of the respondents feared that such amnesty could lead to more coups and instability.

Figure 4: Opinion on Amnesty for military coup perpetrators

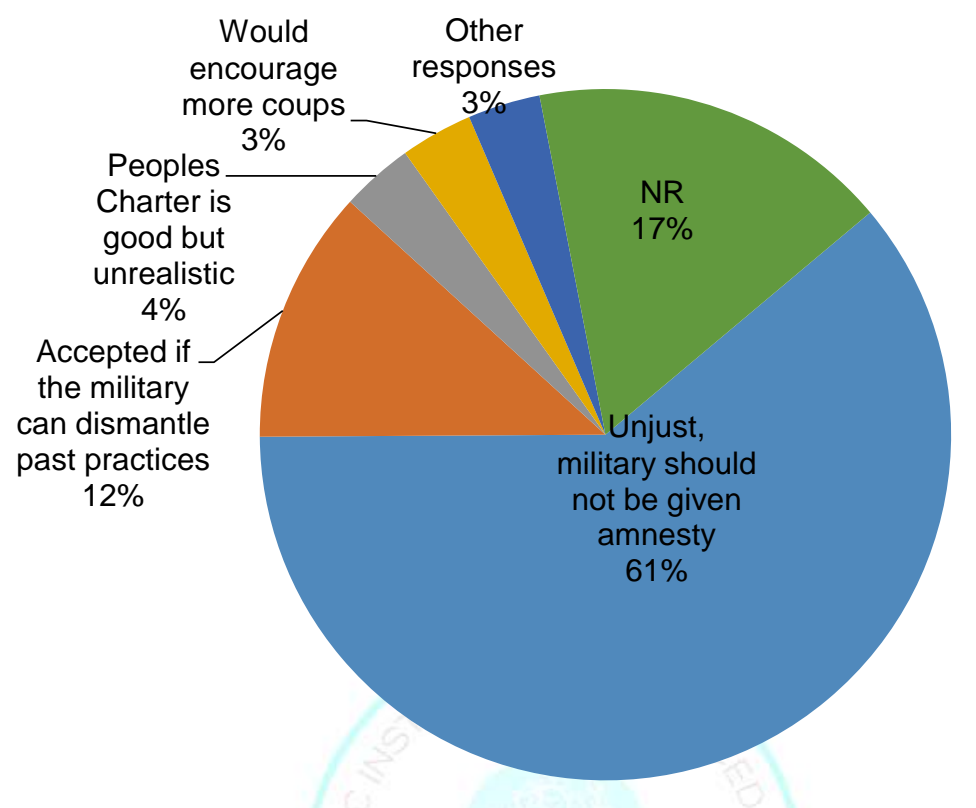

Table 1: Reasons why coup perpetrators should (not) be held accountable for their actions

\begin{tabular}{|l|l|}
\hline $\begin{array}{l}\text { Reasons why the coup perpetrators should or should } \\
\text { not be held accountable for their actions }\end{array}$ & \\
\hline Yes, they should be held accountable because: & Total \\
\hline To be a deterrent for others & $12 \%$ \\
Coups are illegal & $34 \%$ \\
Caused suffering to others/country & $14 \%$ \\
Other & $8 \%$ \\
\hline No, they should not be held accountable because: & $22 \%$ \\
\hline It may lead to other conflicts & $5 \%$ \\
This coup is beneficial for the country & $14 \%$ \\
Other & $3 \%$ \\
\hline TOTAL & 59 respondents \\
\hline
\end{tabular}

\section{Conclusion}

The issue of amnesty has been much discussed in Fiji since 1987 and while data shows that many people do not regard it in a positive light and consider it unjust, respondents have also acknowledged that the military is too strong at this stage to be held accountable. In Fiji, the military is well versed in portraying itself positively to the people and they sense some 
acceptance amongst the public of their self-awarded amnesty because of the belief that the coup has been, in some ways, beneficial. To some extent, their views are justified as Bainimarama's interim government was able to dismantle some structures and policies that were deeply divisive. However, there is also uneasiness with the growing strength of the military. This can for instance be seen from the 2013 Immunity Act, which is so tightly drafted in order to preserve the military's power. In the 2013 Constitution of Fiji, immunity has been entrenched through Acts 158 (1), (2) and (3), which states that

(1) Notwithstanding anything contained in this Constitution, this Chapter and any immunity granted or continued in this Chapter shall not be reviewed, amended, altered, repealed or revoke.

(2) Notwithstanding anything contained in this Constitution, no court or tribunal shall have the jurisdiction to accept, hear or make any decision or order with respect to any challenge against the provisions of this Chapter and any immunity granted or continued in this Chapter.

(3) No compensation shall be payable by the State to any person in respect of damage, injury or loss to his or her property or person caused by or consequent upon any conduct from which immunity has been granted under this Chapter. (Government of Fiji, 2013: 99,100). [emphasis added]

All these clauses ensure that the military cannot be held accountable in any form even in future. This law may be contested at some point but it is unlikely that this would be done in a local court as Acts 158(2) and (3) sets limitations on this avenue of seeking justice.

As stated above, transitioning countries need to be careful in striking a balance between demanding justice and accountability and granting amnesty when the perpetrators are still in power or continue to hold significant influence. In Fiji, Bainimarama and many people associated with him continue to be in power through the 2014 democratic elections. This fact and the significant militarisation of Fiji's civil service indicate that military influence is entrenched and will continue to be part of the country's political landscape for many years to come. In such a scenario, amnesty is unlikely to be contested by the victims. This is important as Fiji's history is silent about the human rights violations that have occurred during times of coups, due to stringent media censorship. There have been some reports of human rights violations from international media and international NGOs, but these only cover a small number of such incidences. Bainimarama has carried out a number of significant structural and policy reforms in Fiji that were unthinkable in the past. However, he has been silent regarding military reforms. As he now holds power democratically, this would be an ideal time for him to encourage military reforms in Fiji as he has the mandate from the people and also strong support from the military; "Many senior military officers have come out openly saying they prefer Bainimarama to lead the country..." said Professor Brij Lal in an interview with ABC News (2014). However, it remains to be seen if Bainimarama is genuinely interested in developing Fiji towards stability and towards reforming the military that is subservient to the democratic government or whether it is simply empty rhetoric. 


\section{References}

i. $\quad$ ABC News, 2014. Fiji expert says Commodore Bainimarama has continued military support in election tilt, 17 January. [Online] Available at:http://www.abc.net.au/news/2014-01-17/an-fijiexperts-say-commodore-bainimarama-has-continued-militar/5205284[Accessed 10 February 2017]

ii. Amnesty International USA, 2017. Defend the Defenders. [Online] Available at:http://www.amnestyusa.org/our-work/issues/prisoners-and-people-at-risk/human-rightsdefenders[Accessed 1 January 2017]

iii. Ball, N.,2004. Dilemmas of Security Sector Reform: Response to SSR in Developing and Transitional Countries. In: Clem McCartney, Martina Fischer \& Oliver Wils eds. Security Sector Reform: Potentials and Challenges for Conflict Transformation. Berlin: Berghof Research Center for Constructive Conflict Management.

iv. Chang, K., 2008. After the Storm of 2000. Fiji's Troubled Path Toward Justice and Reconciliation. In: Salim, W \& Sagoo, K eds.Sustaining a Resilient Asia-Pacific Community. Hawaii: East-West Center \& Cambridge Scholars Publishing.

v. Chauvet, L., Collier, P. \& Hoeffler, A., 2010. Paradise Lost: The Costs of State Failure in the Pacific. Journal of Development Studies, 46(5), pp. $961-980$.

vi. Citizens' Constitutional Forum, 2005. Submission to the Sector Standing Committee on Justice, Law and Order Regarding the Promotion of the Reconciliation, Tolerance and Unity Bill. Suva: CCF.

vii. Commission on Human Rights, 1997. Question of the impunity of perpetrators of human rights violations (civil and political). Revised final report prepared by Mr. Joinet pursuant to SubCommission decision 1996/119. UN, Social and Economic Council. [Online]Available at:http://www.unhchr.ch/huridocda/huridoca.nsf/(Symbol)/E.CN.4.sub.2.1997.20.Rev.1.En. [Accessed 27 October 2008]

viii. Collier, P., Elliott, V.L., Hegre, H., Hoeffler, A., Reynal-Querol, M. \& Sambanis, N., 2003. Breaking the Conflict Trap: Civil War and Development Policy. Washington, DC: World Bank and Oxford University Press.

ix. Cook, T., 1997. Introduction. Transitional Justice in East Asia and its Impact on Human Rights. Series 1(8).

x. $\quad$ Deng, F.M., Kimaro, S., Lyons, T., Rothchild, D., \& Zartman, W. I. eds., 1996. Sovereignty as Responsibility: Conflict Management in Africa. Washington, D.C.: Brookings Institution Press.

xi. Freeman, M., 2009. Necessary Evils: Amnesties and the Search for Justice. New York: Cambridge University Press.

xii. $\quad$ Galtung, J., 1969. Violence, Peace, and Peace Research.Journal of Peace Research, 6(3), pp. 167191.

xiii. Government of Fiji, 2013a. Constitution of the Republic of Fiji. Suva: Fiji Government.

xiv. Human Rights Watch, 2009. Selling Justice Short, Why Accountability Matters for Peace. New York: Human Rights Watch.

xv. Human Rights Watch, 2005. Policy Paper: The Meaning of "The Interests of Justice" in Article 53 of the Rome Statute. New York: Human Rights Watch, June.

xvi. Iliff, A., 2009. Root and Branch, Tree of Life: Sowing the Seeds of Grassroots Transitional Justice. Debating International Justice in Africa. OTJR Collected Essays, 2008-2010. s.l.: Oxford Transitional Justice Research. 
xvii. International Criminal Court (ICC), 2002. 'Rome Statute of the International Criminal Court', Rome, 1 July. [Online]Available at:http://www.icc-cpi.int/NR/rdonlyres/EA9AEFF7-5752-4F84BE94-0A655EB30E16/o/Rome_Statute_English.pdf[Accessed 7 December 2008]

xviii. Joinet, L.,1997. Revised Final Report. Question of the Impunity of Perpetrators of Human Rights Violations (Civil and Political). ECOSOC, UN. E/CN.4/Sub.2/1997/20/Rev.1. [Online] Availableat:http://ap.ohchr.org/documents/alldocs.aspx?doc id=6960[Accessed 20 October 2008]

xix. Joinet, L., 1985. Study of Amnesty Laws and their Role in the Safeguard and Protection of Human Rights. ECSOC, UN. E/CN.4/Sub.2/1985/16. s.l.: s.n.

xx. Kelly, G. \& Mari, F., 2002. Government Strategies on Victims in Post-Conflict Societies. Ulster: International Conflict Centre, INCORE, University of Ulster/United Nations University

xxi. Kritz, N., 2002. Where We Are and How We Got Here: An Overview of Developments in the Search for Justice and Reconciliation. In: Henkin, A. H.,ed.The Legacy of Abuse: Confronting the Past, Facing the Future. New York: Aspen Institute, University School of Law.

xxii. Lederach, J. P., 2006. Building Peace - Sustainable Reconciliation in Divided Societies. Washington D.C: United States Institute of Peace Press.

xxiii. Malamud-Goti, J., 1990. Transitional Governments in the Breach. Why Punish State Criminals?Human Rights Quarterly, 12(1).

xxiv. Mallinder, L., 2007a. Amnesty, Human Rights and Political Transitions: Bridging the Peace and Justice Divide (Studies in International Law). Oxford: Hart Publishing.

xxv. Mallinder, L., 2007b. Exploring the Practise of States in Introducing Amnesties. Workshop 4 The Legal Framework: International Conference on Building a Future on Peace and Justice. Nuremberg: The Institute of Criminal Law and Criminal Justice Department for Foreign and International Criminal Law, University Geottingen.

xxvi. Mangu, A.M., 2011. The historic contribution of the United Nations to the resolution of conflicts in Southern Africa. ACCORD (African Centre for the Constructive Resolution of Disputes). [Online] Available at:http://www.accord.org.za/ajcr-issues/the-historic-contribution-of-theunited-nations-to-the-resolution-of-conflicts-in-southern-africa/[Accessed 10 January 2017]

xxvii. Méndez, J. E., 1997. Accountability for Past Abuses.Human Rights Quarterly, 19(2),pp. 255-282.

xxviii. Neier, A., 1990. What Should be Done About the Guilty. New York Review of Books, 1(2), pp. 3234 .

xxix. Nino, C. S., 1996. Radical Evil on Trial. New Haven, Connecticut: Yale University Press.

xxx. Office of the United Nations High Commission for Human Rights (OHCHR), 2009. Universal Periodic Review - OHCHR Country Report for Fiji. Human Rights Council. Seventh session. 819 February 201O. A/HRC/WG.6/7/FJI/3. [Online] Available at:https://documents-ddsny.un.org/doc/UNDOC/GEN/Go9/170/01/PDF/G0917001.pdf?OpenElement [Accessed 12 November 2015]

xxxi. Orentlicher, D., 2004. Promotion and Protection of Human Rights: Impunity. ECOSOC, UN. E/CN.4/2004/88. s.l.: s.n.

xxxii. Randelzhofer, A. \& Tomuschat, C. eds., 1999. State Responsibility and the Individual. Reparation in Instances of Grave Violations of Human Rights.Hague: Kluwer Law International.

xxxiii. Sarkin-Hughes, J., 2004. Carrots and Sticks: The TRC and the South African Amnesty Process. Antwerp: Intersentia.

xxxiv. Snyder, J. \& Vinjamuri, L., 2003. 'Trials and Errors: Principle and Pragmatism in Strategies of International Justice.International Security,28(3), pp. 5-44. 
xxxv. Skaar, E., 1999. Truth Commissions, Trials or Nothing? Policy Options in Democratic Transitions.Third World Quarterly, 20(6), pp. 1109-1128.

xxxvi. The Groot Schuur Minute, 1991. Minutes and Accords between the ANC and the South African Government May $1990 \quad$ - February 1991. [Online] Available at:http://www.nelsonmandela.org/omalley/index.php/site/q/03lvo2039/04lvo2103/05lvo2104 Lo6lv02108.htm[Accessed 3 May 2010]

xxxvii. Thoms, O. \& Ron, J., 2007. Do Human Rights Violations Cause Internal Conflict?Human Rights Quarterly, 29(3), pp. 674-705.

xxxviii. Tutu, D., 1999. No Future with Forgiveness. London: Random House.

xxxix. Van den Wyngaert, C., 1980. The Political Offence Exception to Extradition: The Delicate Problem of Balancing the Rights of the Individual and the International Public Order. Kluwer, Hague: s.n.

xl. Yakoob, N., 200o. Political Offender or Serious Criminal - Challenging the Interpretation of Serious, Nonpolitical Crimes in INS v. Aguirre-Aguirre. Georgetown Immigration Law Journal 14(2), pp. $545-588$.

xli. Zalaquett, J., 1992. 'Balancing Ethical Imperatives and Political Constraints: The Dilemma of New Democracies Confronting Past Human Rights Violations.Hastings Law Journal, 43(6), pp. 14251438. 